\title{
Hva har tvillingundersøkelser gitt oss av kunnskap om arveligheten av astma?
}

\author{
Wenche Nystad og Per Magnus \\ Divisjon for epidemiologi, Nasjonalt folkehelseinstitutt, Postboks 4404 Nydalen, 0403 Oslo
}

\section{INTRODUKSJON}

Lenge har det vært kjent at utviklingen av astma og andre atopiske sykdommer har en arvelig komponent, og tidlig på 1900 tallet kom det flere studier som påviste en familiær opphoping av astma og allergi (1-3). Arveligheten av disse sykdommene følger imidlertid ikke klassisk mendelsk arvegang der et enkelt gen spiller en avgjørende rolle. Resultater fra ulike typer genetiske studier indikerer at mange gener kan være involvert $\mathrm{i}$ utviklingen av astma og andre atopiske sykdommer. Selve arvelighetsmønsteret av astma er imidlertid ukjent. Resultater fra flere store tvillingstudier har blant annet bidratt til å øke vår forståelse av hvordan arv og miljø kan bidra til utviklingen av astma og allergi (4-8). Kompleksiteten omkring arveligheten av astma kan være at flere sett av ulike gener er involvert i utviklingen av samme fenotype (genetisk heterogenitet), og at samme sett av gener kan være disponerende for ulike fenotyper som astma, eksem og høysnue. Det kan være miljøfaktorer som bestemmer hvilken fenotype som utvikles. Utfordringen i fremtidig forskning er å forstå samspillet mellom arv og miljø når det gjelder utviklingen av astma og andre atopiske sykdommer.

Denne oversikten baserer seg primært på den kunnskap som tvillingstudier har gitt oss om arveligheten av astma. Tvillingundersøkelser kan være til hjelp for å forstå den relative betydning av gener og miljø for utviklingen av sykdom. Arvelighet er her et mål på hvor stor andel av den totale variasjon i sykdomstendens i befolkningen som kan forklares av variasjon $i$ arveanlegg mellom personer $i$ befolkningen.

\section{HVA ER ASTMA?}

Astma er i dag en av de mest vanlige sykdommer blant barn. Norske undersøkelser har vist at forekomsten av astma er 5\% blant barn i skolealder (9-11). Omkring $75 \%$ debuterer før skolealder, mens en stor andel av disse blir frie for symptomer i løpet av skoletiden, og nye tilfeller dukker opp i løpet av barne- og ungdomsårene samt $\mathrm{i}$ voksen alder (11).

Astma regnes som en inflammatorisk sykdom som karakteriseres ved variabel luftveisobstruksjon (12). Selve inflammasjonsprosessen involverer frigjøring av flere inflammatoriske mediatorer som kan påvirke følsomheten i luftveiene overfor ulike kjemiske stoffer. En slik økt bronkial reaktivitet fører til en forsnevring av luftveiene som gir ulike grader av pusteproblemer. Sykdommen astma har flere forskjellige kliniske ytringsformer som allergisk og ikke-allergisk astma, anstrengelsesutløst astma og yrkesastma. Astma er derfor ikke et entydig fenomen, men kan sees på som navnet på en gruppe helseplager i luftveiene.

I genetiske studier er det viktig å definere presist den fenotypen som skal studeres (13). Når det gjelder astma, er dette vanskelig på grunn av de ulike kliniske ytringsformene som sykdommen har, og som kan variere over tid også innen samme individ. Mange epidemiologiske og genetiske studier av astma har brukt selvrapportert astma, legediagnostisert astma eller pusteproblemer som definisjon på astma. Selv om validiteten av slike utfall har vist seg i flere sammenhenger å være bra, kan det føre til misklassifisering av sykdommen (14-18). På grunn av disse metodeproblemene har genetiske studier av astma og allergi rettet seg i senere tid mer mot målbare biologiske markører for sykdommen (19). Eksempler er bronkial reaktivitet, totalt immunoglobulin E (IgE), spesifikt IgE samt hudtestreaktivitet og lungefunksjon.

\section{TVILLINGSTUDIER}

Den klassiske tvillingstudien går ut på å beregne arveligheten av en sykdom i en befolkning ved å sammenligne graden av likhet mellom eneggede og toeggede tvillingpar (20). Årsaker til likhet for eneggede tvillinger er felles gener og felles familiemiljø. Enegedde tvillinger deler $100 \%$ av den genetiske informasjonen, mens toeggede tvilllinger i gjennomsnitt kun deler 50\%. Årsaker til likhet for toeggede tvillinger er derfor at de har halvparten av sine arveanlegg felles, og at de har felles familiemiljø. Hvis en sykdom er sterkt genetisk betinget, vil sannsynligheten for at begge i paret blant eneggede tvillinger har sykdommen være langt høyere enn blant toeggede tvillinger.

Graden av likhet kan måles ved konkordanstall, og det mest vanlige er probandkonkordans, som uttrykker hvor stor andel av tvillingsøsken av astmatiske tvillinger som også har astma. En proband er en tvilling med astma som deltar $i$ en studie helt uavhengig av forekomsten av astma ellers i familien. En befolkningsbasert spørreskjemaundersøkelse av tvillinger basert på hele eller tilfeldige utvalg, vil inkludere alle tvillinger med astma uavhengig av den andre tvillingen. Konkordanstall kan ikke tallfeste arveligheten, men det kan si noe om hva risikoen er for at ens tvilling har 
astma gitt at en selv har det. Et mål som imidlertid kan gi tolkninger i form av arvelighet er tetrakoriske korrelasjonskoeffisienter. Det betyr at vi beregner korrelasjonen i sykdomstendens mellom tvillinger. Denne beregningsmåten tar utgangspunkt $i$ en observert $2 \times 2$ tabell (tabell 1), og beregner Pearson-korrelasjon i de underliggende sykdomstendenser. På basis av disse tallene blir korrelasjonen 0,81 for eneggede par og 0,23 for toeggede par. I studier av tvillinger blir på denne måten graden av likhet og ulikheter mellom eneggede og toeggede tvillingpar sammenlignet.

Tabell 1. Fordelingen av 412 eneggete og 384 toeggete, mannlige tvillingpar i alderen 18 til 25 år etter astmaforekomst i paret.

\begin{tabular}{lcc}
\hline Første tvilling & \multicolumn{2}{c}{ Andre tvilling } \\
\hline Eneggete par & & \\
& Ikke astma & Astma \\
Ikke astma & 375 & 11 \\
Astma & 13 & 13 \\
\hline Toeggete par & & \\
& Ikke astma & Astma \\
Ikke astma & 341 & 16 \\
Astma & 24 & 3 \\
\hline
\end{tabular}

For å beregne arveligheten er det nyttig å bruke et stidiagram (figur 1). Diagrammet viser de faktorene som gir opphav til fenotypen for den ene (P1) og den andre (P2) tvillingen, og som viser hvordan den observerte korrelasjonen mellom tvillingsøsken er skapt av genetiske og miljømessige faktorer. Den genetiske verdien $(G)$ til tvilling 1 og tvilling 2 er korrelert med koeffisienten 1 hos eneggede par og 0,5 hos toeggede par. Videre er det miljøfaktorer (C) som er felles for begge tvillinger. De miljøfaktorene som ikke er felles for tvillingene $\mathrm{i}$ et par, og som derfor ikke bidrar til likhet mellom tvillingene kalles $\mathrm{E}$.

\section{TVILLINGSTUDIER AV ASTMA}

H. Los, P.E. Potmus og D.I. Boosma har nylig oppsummert litteraturen på dette området (19). En av de første store tvillingstudiene ble gjort ved hjelp av det svenske tvillingregisteret av Edfors-Lubs i 1971 (21). Her deltok ca. 7000 tvillingpar i alderen 46 til 85 år. Konkordansraten for selvrapportert astma blant eneggede tvillinger var $19 \%$, mens den var 5\% blant toeggede tvillinger. Resultatet antyder at astma er genetisk betinget. En australsk studie undersøkte noe senere 3808 tvillingpar i alderen 18-65 år (22). Forekomsten av selvrapportert astma var $13 \%$, og de tetrakoriske korrelasjonene for astma var forskjellig for eneggede $(0,48)$ og toeggede mannlige $(0,09)$ tvillinger, og for eneggede $(0,33)$ sammenlignet med toeggede $(0,12)$ kvinnelige tvillinger. Dette indikerte at variasjonen $\mathrm{i}$ tendens til å få astma i stor grad kan tilskrives gener.

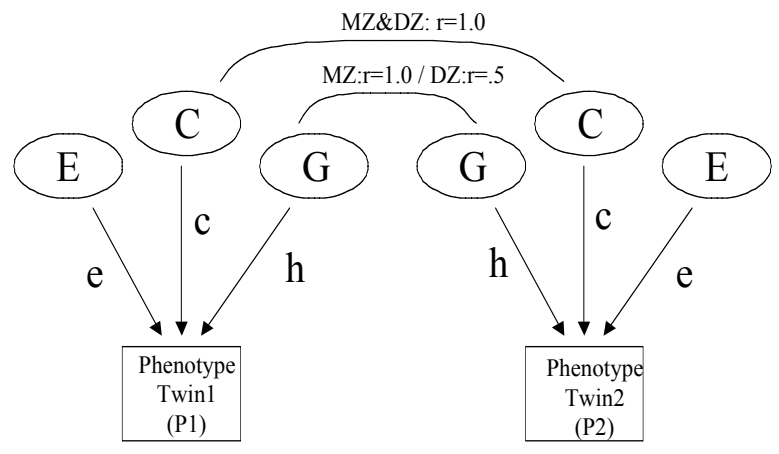

Figur 1. Årsaksmodell der fenotypen $\mathrm{P}$ (for eksempel astmatendens) er en følge av effekter (h) fra gener (G), effekter (c) av miljøfaktorer som er felles for søsken (C) og effekter (e) av miljøfaktorer som ikke er felles for søsken (E). Korrelasjonen mellom genetiske verdier for eneggete (MZ-monozygote) tvillinger er 1,0, mens den er 0,5 for toeggete (DZ-dizygote).

I 1991 publiserte Nieminen et al. en studie av 13888 finske eneggede og toeggede tvillinger av samme kjønn i alderen 17-80 år (23). Diagnosen astma ble gjort ved å koble tvillingregisteret til andre databaser som sykehusregisteret, bruk av medikamenter og dødsårsaksregisteret. Forekomsten av astma var 2\%. Arvelighetsestimatene var 0,68 for kvinner og 0,48 for menn i aldersgruppen 28-59 år, og 0,36 når kjønnene ble slått sammen. I denne studien varierte arveligheten både med kjønn og alder, med synkende arvelighet ved økende alder.

Ved å bruke stianalyse for å vise hvilke faktorer som gir opphav til fenotypen for den ene og den andre tvillingen, og hvordan den observerte korrelasjonen mellom tvillingsøsken var skapt av genetiske og miljømessige effekter viste Duffy et al. at korrelasjonen for selvrapportert astma var 0,65 for eneggede og 0,24 for toeggede tvillinger (4). Arveligheten var 0,60 for kvinner og 0,75 for menn, og modellen viste at den ikke additive genetiske komponenten hadde en sterk effekt for menn, men ikke for kvinner hvor den additive genetiske effekten var langt viktigere. Rundt $24-40 \%$ av variasjonen i tendens til å få astma kunne tilskrives ikke felles miljø, mens felles familiemiljø ikke så ut til å ha noen effekt. Det finnes flere skandinaviske studier av tvillinger som har vist lignende resultater. En svensk studie som inkluderte barn i alderen 7-9 år viste at korrelasjonen for foreldrerapportert astma var 0,79 for eneggede gutter og 0,64 for eneggede jenter, med korrelasjoner på henholdsvis 0,25 og 0,27 for toeggede gutte- og jentetvillinger (5). Variasjonen i tendens til å få astma kunne i stor grad $(76 \%$ for gutter og $64 \%$ for jenter) tilskrives gener. Det var heller ikke i denne studien noe bidrag fra felles miljø hverken for gutter eller jenter. Den genetiske korrelasjonen for astma og allergi var 0,90, som indikerer at det kan være et sett av felles gener for disse sykdommene. En stor norsk studie av tvillinger i alderen 18-35 år støttet resultatene fra den svenske studien, ved å vise at $75 \%$ av variasjonen i tendens til å få astma ble forklart av gener (6). 
De resterende $25 \%$ ble forklart av miljøfaktorer som ikke var felles. Forekomsten av selvrapportert astma var i denne studien $6 \%$, og det var ingen kjønnsforskjeller. En annen studie fra Finland av 16-åringer viste samme tendens med en arvelighet av astma på $79 \%$, mens de gjenstående $21 \%$ skyldes miljøfaktorer uten noe bidrag fra felles miljø (7). I denne studien var også forekomsten av astma langt høyere blant tvillinger som hadde foreldre med astma (15\%) enn blant tvillinger uten foreldre med astma (3\%). En annen studie av Skadehaug et al. (1999) underbygger funnene nevnt over med en arvelighet på $73 \%$ blant tvillinger i alderen 12-41 år (8).

Disse tvillingstudiene har vist at variasjonen i tendens til å få astma kan tilskrives gener. Miljøfaktorer er imidlertid også av en vesentlig betydning siden de bidrar med omkring 25\% av variasjonen. Et annet viktig funn er at alle disse undersøkelsene uansett hvor de er utført viser samme tendens uten noe bidrag fra felles miljø. De fleste av studiene brukte selvrapportert astma som utfall, men det finnes også tvillingstudier som har brukt bronkial reaktivitet, hudtest, total og spesifikt immunoglobulin E (IgE) og lungefunksjon som utfall.

\section{Bronkial reaktivitet}

Astma karakteriseres ved en økt følsomhet i luftveiene (bronkial reaktivitet), men ikke alle med økt bronkial reaktivitet har astma. Likevel kan arveligheten av bronkial reaktivitet si oss noe om arveligheten av astma ved at dette er to fenotyper som henger sammen. Det finnes noen få og svært små studier som har brukt bronkial reaktivitet som utfall. I 1974 viste Konig og Godfrey at konkordansen for anstrengelsesutløst astma var høyere for eneggede (75\%) enn for toeggede (14\%) tvillingpar (24). I 1984 målte Hopp og medarbeidere bronkial reaktivitet på 61 eneggede og 46 toeggede tvillingpar $i$ alderen 6-31 år som ble rekruttert via media (25). Intraklassekorrelasjonen for bronkial reaktivitet var høyere for eneggede $(0,67)$ enn for toeggede $(0,34)$ tvillinger. Arvelighetsestimatet var 0,66. Dette resultatet antyder at mye av variasjonen i tendens til bronkial reaktivitet kan tilskrives gener.

\section{Immunoglobulin E (IgE)}

Total IgE er en indikator på pasientens atopiske status, og forhøyede verdier sannsynliggjør allergi. I 1974 undersøkte Bazaral og medarbeidere 54 eneggede og 39 toeggede tvillingpar i alderen 45-55 år (26). I tillegg inkluderte de 10 eneggede og 13 toeggede tvillingpar $\mathrm{i}$ alderen 2-10 år. Arvelighetsestimatet for totalt IgE var 0,58 blant voksne, mens det var 0,79 blant barn. Disse resultatene antydet at totalt IgE var sterkere genetisk betinget blant barn enn voksne. En reanalysering av de samme dataene i 1994, hvor det også ble gjort genetisk modellering viste at variasjonen $\mathrm{i}$ tendens til forhøyet IgE i stor grad ( $80 \%$ blant voksne og $93 \%$ blant barn) kan tilskrives gener (27). En annen studie fra Sveits som inkluderte 30 eneggede og 20 toeggede tvillingpar hvor minst en i paret skulle være atopisk, viste at konkordansen for atopi var høyere blant eneggede (57\%) enn for toeggede (27\%) tvillinger (28). Studien av Hopp og medarbeidere som er nevnt over målte også total IgE, og de fant en signifikant høyere korrelasjonskoeffisient blant eneggede $(0,82)$ enn blant toeggede $(0,52)$ tvillinger $(25)$. En annen studie hvor det også ble gjort genetisk modellering av data viste at variasjonen i IgE kan tilskrives gener (56\%) samt ikke felles miljø (44\%) (29). Felles miljø hadde ingen effekt.

\section{Spesifikt IgE og kutantest}

Flere av studiene som er nevnt over inkluderte også måling av spesifikt IgE og en hudtest. En hudtest påviser sensibiliserte mastceller i huden, og en positiv test tyder på IgE-sensibilisering. En negativ test utelukker imidlertid ikke allergi. Derfor sier testen alene lite om grad av eller tilstedeværelse av sykdom. Resultatene fra disse studiene er litt sprikende avhengig av hvilket type allergen som er anvendt og test som er gjort. Den sveitsiske studien brukte hudtest og målte spesifikt IgE mot husstøvmidd (Dermatophagoides pteronyssinus), timotei, bjørk, hassel, hund, katt og hest (28). Konkordansen for spesifikt IgE var ikke statistisk forskjellig for eneggede og toeggede tvillinger. Det var imidlertid en tendens til høyere konkordans blant eneggede enn toeggede tvillinger når de så på de enkelte allergener hver for seg, men det var kun for timotei at konkordansen var statistisk signifikant høyere for eneggede enn toeggede tvillinger. I studien til Hopp og medarbeidere var korrelasjonen høyere blant eneggede $(0,82)$ enn toeggede $(0,46)$ tvillinger med en arvelighet på 0,72 når de brukte en total hudtestskår som utfall (25). Når de så på hver enkelt allergen i hudtesten, var resultatene svært variable, og det var bare for blandet gress at det var en signifikant forskjell mellom eneggede og toeggede tvillinger med en arvelighet på 0,73 . Denne studien antydet at variasjonen $i$ tendens til en total reaktivitet på hudtest kan primært tilskrives gener. En annen studie av Hanson og medarbeidere som brukte tre ulike allergener, fant ingen forskjell mellom eneggede og toeggede tvillinger hverken for spesifikt IgE eller hudtestreaktivitet (29). I 1998 publiserte Sluyter og medarbeidere resultatene fra det australske tvillingregisteret hvor 70 eneggede og 112 toeggede tvillinger var testet for 11 av de mest vanlige allergenene (30). Blant de inkluderte skulle minst en i paret ha reagert på raigress, og de undersøkte videre ved hjelp av IgE-målinger de ulike komponentene $\mathrm{i}$ raigress. Resultatene viste at IgE-responsen for spesifikke komponenter av raigress primært kan tilskrives miljøfaktorer. Den samme studien viste at selv om det var en tendens til høyere konkordans mellom eneggede (54\%) enn toeggede (37\%) tvillinger for husstøvmidd (Dermatophagoides pteronyssinus), var det en signifikant forskjell mellom eneggede og toeggede tvillinger 
kun for to komponenter av husstøvmidd (30). Denne studien viste at IgE-responsen for husstøvmidd er delvis påvirket av gener, men effekten er mindre enn reguleringen av totalt IgE. Resultater fra de tvillingstudiene som har inkludert hudtest og spesifikt IgE viser at variasjonen i tendens til å reagere på ulike allergener i større grad kan tilskrives miljøfaktorer enn det som er tilfelle hvis en benytter andre utfall på astma og allergi. Strachan og medarbeider konkluderer også i sin studie av 340 eneggede og 533 toeggede tvillinger i alderen 18 til 72 år at miljøfaktorer har en modifiserende effekt på utviklingen av allergi (31). Konklusjonen baserer seg på den observasjonen at eneggede tvillinger ofte var diskordante i sitt allergiske uttrykk.

\section{Lungefunksjon}

Nedsatt lungefunksjon kan være et uttrykk for luftveislidelser, men lungefunksjonsmålinger alene er sjelden tilstrekkelig for å diagnostisere astma. Lungefunksjon påvirkes primært av høyde, vekt, alder, kjønn og etnisk bakgrunn (32). I tillegg vil miljøfaktorer som sigarettrøyking, luftveisinfeksjoner og ulike typer yrkeseksponering som for eksempel støv virke på lungefunksjonen. Et av de interessante spørsmål i denne sammenheng er om variasjonen i lungefunksjon kun er en funksjon av vår sterkt arvelige kroppskomposisjon som høyde og vekt eller om andre genetiske faktorer også bidrar.

I 1981 publiserte Hubert og medarbeidere en studie av lungefunksjonen blant 127 eneggede og 141 toeggede tvillingpar i alderen 41-56 år (33). De brukte forsert vital kapasitet (FVC) og forsert ekspiratorisk volum i 1 sekund (FEV1) som utfall. Intraklassekorrelasjonen for FVC var 0,72 for eneggede og 0,16 for toeggede tvillinger med en arvelighet på 0,91 . For FEV1 var intraklassekorrelasjonen henholdsvis 0,71 for eneggede og 0,33 for toeggede tvillinger, mens den estimerte arveligheten var 0,77. De kontrollerte for alder, høyde og vekt, og i tillegg tok de inn røyking $\mathrm{i}$ analysen, men arveligheten var fremdeles 0,74 for FEV1. Da de også tok hensyn til graden av likhet mellom eneggede tvillingpar og kontrollerte for hvor hyppig disse var sammen for å unngå en overestimering av den genetiske faktoren, varierte arvelighetsestimatet for FEV1 fra 0,51 til 0,80 avhengig av hvor ofte tvillingene var sammen. Denne studien viste at variasjon i lungefunksjon i stor grad kan tilskrives gener. Senere er det kommet andre studier av lungefunksjon som bekrefter dette funnet (34-36).

\section{DISKUSJON}

Denne oversikten viser at variasjonen i tendens til å få astma i stor grad kan tilskrives arv. Resultatene fra de store spørreskjemaundersøkelsene av tvillinger indikerer at det er en sterk additiv genetisk effekt, og at den andre viktige komponenten er ikke felles miljø som bidrar med omkring 25\%. Et viktig funn er at felles miljø ikke bidrar til variasjonen i tendens til å få astma. Dette er i kontrast til resultatene fra en rekke epidemiologiske studier som viser at for eksempel røyking, virusinfeksjoner og faktorer i innemiljøet som fukt og mugg, som deles av tvillinger mens de er barn, kan påvirke utviklingen av astma $(37,38)$. En forklaring på forskjellen i resultater fra tvillingstudier og tradisjonelle epidemiologiske studier kan være at felles miljø kun har betydning blant de personer som er genetisk disponert for å utvikle astma. En slik interaksjon mellom genotype og miljø vil i tvillinganalyser være "skjult" i den genetiske komponenten og overestimere effekten av gener. En annen forklaring på at det ikke er effekt av felles miljø i tvillingstudier kan være tvillingundersøkelser som metode. Det er et puslespill å finne ut om en familiær opphopning av astma skyldes arv, miljø, interaksjon mellom arv og miljø, felles ikke genetiske faktorer eller en interaksjon mellom alle disse. Tvillingstudier kan belyse dette grovt, men den statistiske modellen kan også overestimere effekten av gener. I den klassiske tvillingmodellen blir en forhøyet korrelasjon mellom eneggede tvillinger sammenlignet med toeggede tvillinger tolket som en genetisk effekt, men effekten av felles miljø kan ligge gjemt i effekten av felles gener, fordi en aldri kan være helt sikker på om eneggede tvillinger har et mer likt miljø enn toeggede tvillinger (39). Det er også systematiske forskjeller på det intrauterine miljøet for eneggede og toeggede tvillinger. Dette kan påvirke intrauterin vekst og utvikling samt modning av enkelte organer som igjen kan påvirke utviklingen av astma. Andre forutsetninger $i$ tvillinganalysen er at tvillingene er representative for befolkningen, og at den selvrapporterte zygositeten er korrekt. Disse antagelsene er valide så lenge tvillingene er et tilfeldig utvalg av befolkningen, og det er vist at selvrapportering av zygositet er riktig $i$ 95-98\% av tilfellene (40).

Når det gjelder arveligheten av astma er det mye vi ikke vet. Det gjenstår blant annet å forstå om det er de samme gener som er involvert $i$ astma, bronkial reaktivitet og atopi, samt om det er en interaksjon mellom gener og miljø, og om det er aldersrelaterte genetiske effekter. Det er få og svært små tvillingstudier som har brukt bronkial reaktivitet og atopi som utfall, og i de fleste av disse studiene ble det ikke gjort genetisk modellering. Resultatene viste imidlertid at variasjonen $i$ totalt IgE primært kan tilskrives gener og miljøfaktorer som ikke er felles for tvillingene. Studiene med bronkial reaktivitet viste også en tendens til en sterk genetisk effekt. Arveligheten av total IgE hadde en tendens til å synke med økende alder, og i studien til Nieminen varierte arvelighetsestimatet for astma med alder. Dette viser at det kan være forskjeller mellom voksne og barn når det gjelder den genetiske variasjonen i tendens til å få astma. Resultatene fra tvillingstudier som brukte spesifikt IgE og hudtestreaktivitet som utfall, viste at miljøfaktorer kan bidra mer enn arv når det gjelder variasjon i tendens til å utvikle slike trekk. På dette området trenger vi imidlertid langt flere studier. 


\section{Studier av enkeltgener og astma}

Tvillingstudier gir generelle svar. Koblings- og assosiasjonsundersøkelser med bruk av kandidat- og markørgener gir informasjon om enkeltgenenes betydning. Det er naturlig å lete etter assosiasjoner til gener som påvirker den inflammatoriske prosessen. Cookson har nylig oppsummert litteraturen på dette feltet (41). Hans konklusjon er at det er gjentatte studier som viser at loci på kromosom nr. 5,6,12 og 13 er koblet eller assosiert med astma. På kromosom 5 dreier det seg om gener som er knyttet til flere cytokiner, mens det dreier seg om gener i HLA-området på kromosom 6. Det er stor aktivitet knyttet til studier som utnytter "single nucleotide polymorphisms" (SNP) innen disse kromosomområdene. Som et eksempel på forskningen kan nevnes en kohortstudie av 411 barn som ble genotypet for genet som koder for interleukin 12. Dette genet sitter i det interessante området på kromosom 5. Man fant at barn som var heterozygote for en spesiell polymorfisme i promotorområdet for dette genet oftere utviklet alvorlig astma. De fant det samme i en annen kohort av 433 barn (42).

\section{OPPSUMMERING OG KONKLUSJON}

Resultatene fra en rekke tvillingstudier har vist at utviklingen av astma, allergi og lignende fenotypiske trekk er under en sterk genetisk kontroll. Det er fremdeles en rekke forskningsspørsmål som belyses med tvillingstudier, men i dag er aktiviteten betydelig høyere på koblingsstudier og assosiasjonsstudier med bruk av kandidatgener eller markørgener. Å foreslå kandidatgener krever forståelse av patogenesen. I den senere tid er det identifisert flere kromosomområder med gener som enten er koblet eller assosiert med astma og allergi. Noen av disse områdene viser også kobling til andre enkeltgen-lidelser og andre immunologiske sykdommer. Dette forskningsområdet er under stor utvikling, og det blir spennende i de nærmeste årene å se om det er riktig at ett eller noen få loci kan forklare mye av disposisjonen for astma eller om det går som pessimistene sier: at vi ikke vil finne noen gener som alene har vesentlig betydning, mye på grunn av astmafenotypens heterogene natur. Utfordringen i fremtidig forskning er også å forstå samspillet mellom arv og miljø.

\section{REFERANSER}

1. Cooke RA, van der Veer A. Human sensitization. J Immunol 1916; 1: 201-305.

2. Rackemann FM. Studies in asthma II. An analysis of two hundred and thirteen cases in which the patients were relieved for more than two years. Arch Intern Med 1928; 41: 346-69.

3. Spain WC, Cooke RA. Studies in specific hypersensitiveness. XI. The familial occurrence of hayfever and bronchial asthma. J Immunol 1924; 9: 521-69.

4. Duffy D, Martin N, Battistutta D, Hopper J, Mathews J. Genetics of asthma and hay fever in Australian twins. Am Rev Respir Dis 1990; 142: 1351-8.

5. Lichtenstein PSM. Genes, environments, and sex: factors of importance in atopic diseases in 7-9-year-old Swedish twins. Allergy 1997; 52: 1079-86.

6. Harris JR, Magnus P, Samuelsen SO, Tambs K. No evidence for effects of family environment on asthma. $\mathrm{Am}$ J Respir Crit Care Med 1997; 156: 43-9.

7. Laitinen T, Rasanen M, Kaprio J, Koskenvuo M, Laitinen LA. Importance of genetic factors in adolescent asthma. a population-based twin-family study. Am J Respir Crit Care Med 1998; 157: 1073-8.

8. Skadhauge L, Christensen K, Kyvik K, Sigsgaard T. Genetic and environmental influence on asthma: a population-based study of 11,688 Danish twin pairs. Eur Respir J 1999; 13: 8-14.

9. Skjønsberg OH, Clench-Aas J, Leegaard J, Skarpaas IJK, Giæver P, Bartonova A, Moseng J. Prevalence of bronchial asthma in schoolchildren in Oslo, Norway. Allergy 1995; 50: 806-10.

10. Nystad W, Magnus P, Røksund O, Svidal B, Hetlevik Ø. The prevalence of respiratory symptoms and asthma among school children in three different areas of Norway. Pediatr Allergy Immunol 1997; 8: 35-40.

11. Nystad W, Søyseth V, Magnus P. The prevalence of asthma among school children in Norway in 1985-94. Tidsskr Nor Laegeforen 1997; 117: 644-7.

12. Sheffer AL, Bousquet J, Busse WW, Clark T, Dahl R, Evans D, et al. International consensus report on diagnosis and treatment of asthma. Eur Respir J 1992; 5: 601-41.

13. Holgate ST. Asthma genetics: waiting to exhale. Nat Genet 1997; 15: 227-9.

14. Silverman M. Out of the mouths of babes and sucklings: lessons from early childhood asthma. Thorax 1993; 48: 1200-4.

15. Shaw R, Woodman K, Ayson M, Dibdin S, Winkelman R, Crane J. Measuring the prevalence of bronchial hyper-responsiveness in children. Int J Epidemiol 1995; 24: 597-602.

16. Toelle BG, Peat JK, Salome CM, Mellis CM, Woolcock AJ. Toward a definition of asthma for epidemiology. Am Rev Respir Dis 1992; 146: 633-7. 
17. Peat JK, Toelle BG, Salome CM, Woolcock AJ. Predictive nature of bronchial responsiveness and respiratory symptoms in one year cohort study of Sydney schoolchildren. Eur Respir J 1993; 6: 662-9.

18. Nystad W, Stensrud T, Rijcken B, Hagen J, Magnus P, Carlsen K-H. Wheezing in school children is not always asthma. Pediatr Allergy Immunol 1999; 10: 58-65.

19. Los H, Postmus PE, Boomsma DI. Asthma genetics and intermediate phenotypes: A review from twin studies. Twin Research 20021; 4: 81-93.

20. Magnus P, Harris JR, Nystad W, Tambs K. Hva kan tvillingforskning fortelle om årsaker til sykdom? Tidsskr Nor Logeforen 1999; 119: 3317-21.

21. Edfors-Lubs ML. Allergy in 7000 twin pairs. Acta Allergol 1971; 25: 249-85.

22. Hopper JL, Hannah MC, Macaskill GT, Mathews JD. Twin concordance for a binary trait: III. A bivariate analysis of hayfever and asthma. Genet Epidemiol 1990; 7: 277-89.

23. A population-based study of bronchial asthma in adult twin pairs. Chest 1991; 100: 70-5.

24. Exercise-induced bronchial lability in monozygotic (identical) and dizygotic (nonidentical) twins. $J$ Allergy Clin Immunol 1974; 54: 280-7.

25. Hopp RJ, Bewtra K, Watt GD, Nair NM, Townley RG. Genetic analysis of allergic disease in twins. J Allergy Clin Immunol 1984; 73: 265-70.

26. Bazaral M, Orgel HA, Hamburger RN. Genetics of IgE and allergy: Serum IgE levels in twins. J Allergy Clin Immunol 1974; 54: 288-304.

27. Duffy DL. Asthma and allergic diseases in Australian twins and their families. 1994. Thesis, Department of Medicine, University of Queensland, Brisbane, Australia.

28. Wuthrich B, Baumann E, Fries RA, Schnyder UW. Total and specific IgE (RAST) in atopic twins. Clin Allergy 1981; 11: 147-54.

29. Hanson B, McGue M, Roitman-Johnson B, Segal NL, Bouchard TJ, Blumenthal MN. Atopic disease and immunoglobulin E in twins reared apart and together. Am J Hum Genet 1991; 48: 873-9.

30. Sluyter R, Tovey ER, Duffy DL, Britton WJ. Limited genetic control of specific IgE responses to rye grass pollen allergens in Australian twins. Clin Exp Allergy 1998; 28: 322-31.

31. Strachan DP, Wong HJ, Spector TD. Concordance and interreationship of atopic diseases and markers of allergic sensitization among adult female twins. J Allergy Clin Immunol 2001; 108: 901-7.

32. Pedersen OF, Miller MR. Lung function. In: Annesi-Maesano I, Gulsvik A, Viege G, eds. Respiratory epidemiology in Europe. Sheffield: European Respiratory Society Journals, 2000: 167-98.

33. Hubert HB, Fabsitz RR, Feinleib M, Gwinn C. Genetic and environmental influences on pulmonary function in adult twins. Am Rev Respir Dis 1982; 125: 409-15.

34. Hankins D, Drage C, Zamel N, Kronenberg R. Pulmonary function in identical twins raised apart. Am Rev Respir Dis 1982; 125: 119-21.

35. Kawakami Y, Shida A, Yanamoto H, Yoshikawa T. Pattern of genetic influence on pulmonary function. Chest 1985; 87: 507-11.

36. Redline S, Tishler PV, Lewitter FI, Tager IB, Munoz A, Speizer FE. Assessment of genetic and nongenetic influence on pulmonary function. Am Rev Respir Dis. 1987; 135: 217-22.

37. Nafstad P, Kongerud J, Botten G, Hagen JA, Jaakkola J. The role of passive smoking in the development of bronchial obstruction during the first 2 years of life. Epidemiology 1997; 8: 293-7.

38. Rothman KJ. Modern epidemiology. Boston: Little, Brown and Company, 1986.

39. Hopper JL. Why common environmental effects are so uncommon in the litterature. In: Spector TD, Snieder H, Mac Gregor AJ, eds. Advances in twin and sib-pair analysis. Oxford: Oxford University Press, 2000: 15165.

40. Magnus P, Berg K, Nance WE. Predicting zygosity in Norwegian twin pairs born 1915-1960. Clin Genet 1983; 24: 103-12.

41. Cookson WOC. Asthma genetics. Chest 2002; 121: 7S-13S.

42. Morahan G, Huang D, Wu M, Holt BJ, White GP, Kendall GE, Sly PD, Holt PG. Association of IL12B promoter polymorphism with severity of atopic and non-atopic asthma in children. Lancet 2002; 360: 455-59. 